\title{
Examining the Health-Seeking Behaviours of Migrant Female Head Porters in the Kumasi Metropolis, Ghana
}

\author{
Simon Boateng \\ Social Sciences Department, St. Monica's College of Education, P. O. BOX MA 250, Mampong-Ashanti, Ghana. \\ Email: boateng.simon@yahoo.com
}

\begin{abstract}
This study is a follow-up to an earlier publication which looked at migrant female head porters' enrolment in, renewal and utilisation of the National Health Insurance Scheme in the Kumasi Metropolis. Head porterage in the large urban markets in Ghana comes with several health issues. Research has shown that migrant female head porters are exposed to several physical, social and psychological health risks in their daily encounters with clients. This research, therefore, aims at examining the health-seeking behaviours of migrant female head porters in the Kumasi metropolis using the dimensions of availability, accessibility, affordability, accommodation and acceptability. The researcher used the cross-sectional survey in the context of quantitative approaches. A total of 378 respondents were sampled from the following markets (Asafo, Adum shopping centres, Bantama and Kejetia) in which the migrant female head porters operate through convenient snowball sampling technique. Charts, percentages and tables were used in the data analysis. The study uncovered that the most (67\%) preferred healthcare provider among the female head porters was over-the-counter chemical seller. Meanwhile, these service providers pose a serious health risk as they constitute a major source of self-medication. Further discoveries showed that affordability was the primary constraint to quality health-care as $76 \%$ of the respondents bemoaned charges at healthcare facilities. The study recommends a comprehensive policy interventions to enhance mass enrolment of female head porters unto the National Health Insurance Scheme to reduce the cost of healthcare among head porters. Finally, to protect the interest of the female head porters, they should form a well-structured and coordinated association to give them a united front to pursue their collective interest and protect them from the challenges they face including the difficulties they face in accessing healthcare.
\end{abstract}

Keywords: Migrant female head porters, health-seeking behaviours, Over-the-Counter Chemical Seller, Kumasi Metropolis, National Health Insurance Scheme

\section{Introduction}

The economic, social and environmental privileges of society have been instrumental causes of migration from the less developed areas to the developed areas globally ${ }^{[14,19]}$. Ghana is no exception. The lack of social infrastructure and job opportunities, poverty, tribal wars and conflicts, socio-cultural practices that dehumanise females are some of the major factors that cause the migration of young women from the northern areas to the southern areas to seek for greener pastures and comfortable lives in Ghana ${ }^{[6,10,16,24]}$. The Ghana Statistical Service ${ }^{[20]}$ and Wrigley-Asante ${ }^{[29]}$, posit that poverty level is high in the northern Ghana and females are the worst affected compared to men. In view of this, these young women migrate to the southern urban areas to engage in various forms of menial jobs, particularly head porterage ${ }^{[16]}$. Head porters are people who carry and transport goods from one place to another at a negotiable fee with their clients ${ }^{[1]}$. Migrant females who are involved in this business are referred to as "kayayoo" in the greater Accra and "paa oo paa" in the Ashanti Region ${ }^{[17]}$.

Though majority of the researches ${ }^{[5,6,10,22,30]}$ on migration of female head porters in Ghana concur that the quest to meet economic needs is the over-arching reason that push these girls to migrate down south, other authors reveal that other socio-cultural factors backstop their movements. For example, the practice of arranged marriage where young females are given out to marriage without their consent is a factor that fuel the north-south migration ${ }^{[12]}$. This has been confirmed by ${ }^{[24]}$ whose study revealed that about $17 \%$ of interviewed young migrants had fled from arranged marriages. The practice of polygamy also creates unwarranted competition among women and in a bid to please their husbands and win their love, 
most women migrate down south to undertake menial jobs to garner the needed finance and necessary assets ${ }^{[12,24]}$.

For these reasons afore-stated, females in these areas then tend to migrate to the southern urban areas with the intention of bridging the poverty gap and to raise their social status. However, it must be noted that migration of females was initially frowned upon and females were highly discouraged to migrate to the south. That notwithstanding, families who used to frown upon this act now encourage their wards to embark on these trips because of its benefits ${ }^{[1]}$. Currently, families support and sponsor their female wards for its lucrativeness (ibid). Meanwhile, these young females find themselves in head porterage activities when they travel to the south.

It is worth noting that migration and health are linked in many ways. For instance, migrants can transmit communicable and non-communicable diseases in their quest to move from the northern areas to the southern urban areas

${ }^{[28]}$. Migrants female head porters can also contract diseases in the course of their movements to various destinations ${ }^{[3,16]}$. Most of these migrants' female head porters are faced with a lot of challenges to quality health-care as a result of language and socio-economic barriers. Also, it is imperative to understand that quality health care in Ghana is expensive and as such only the few affluent people afford it at the expense of the poor, especially the migrant female head porters who live below the standard income level ${ }^{[16]}$. Some of these challenges include the cost involved in attaining quality healthcare ${ }^{[5,8,16,27]}$. Distance between health service providers and the patient is also a challenge to quality healthcare in Ghana, particularly for the vulnerable such as the migrant female head porters $[9,16,17,18,25,26]$. For instance, distance can impede accessing quality healthcare as the patient may not have the means to get to the health service provider. Again, health insurance coverage is another challenge in acquiring quality health care since the insurance may not cover certain health services adequately ${ }^{[16,21,23]}$

As a result, these challenges affect the health seeking-behaviours of the migrant female head porters as they resort to over-the-counter prescriptions, unprofessional traditional medicines and treatments among others ${ }^{[4]}$. Several literature ${ }^{[1,}$ 9, 16, 17, 18, 21, 23, 25, 26] have copiously dealt with migrant head porters and their economic status; and national health insurance accessibility. Akuoko et al. ${ }^{[4]}$ digressed by specifically examining female head porters access to quality healthcare services in the Kumasi Metropolis culminating into a research gap of their health-seeking behaviours. Therefore, this study specifically seeks to examine the health-seeking behaviours (medical practices) of the migrant female head porters in the Kumasi Metropolis.

\section{Materials and Methods}

\subsection{Research Design}

The study employed the case study approach which enjoins a holistic understanding of the unit under investigation. Yin ${ }^{[31]}$ posits that the choice of case study as a research design usually arises when "how" or "why" questions are being posed, when the investigator has little control over events, and when the focus is on a contemporary phenomenon within some real-life context.

The target population for this research encapsulates migrant female head porters within the Central Business District in the Kumasi metropolis which has over 23,000 female head porters aged between 12-40 years in the Kumasi metropolis ${ }^{[2,13]}$. The migrant female head porters often operate in the major marketing areas which are places where they can quickly get shoppers' and travellers' luggage to carry. According to Baah-Ennumh et al. ${ }^{[13]}$, they often live in clusters or groups, and this influenced the choice of sampling method the study adopted.

The study sampled 378 participants across the five market areas in the Central Business District. These include Adum shopping centre, Asafo, Kumasi central, Bantama and Kejetia markets. The study employed intuitive method of sample size determination to select the number of participants to include in the study. This is because there are no reliable, up-todate estimates of the total population of migrant female head porters who operate in the Kumasi Metropolis ${ }^{[13]}$. Thus, it makes it virtually impossible to get a sampling frame from which the sample size could be selected. Convenience snowball technique was employed to conveniently select respondents at first and further asked to recommend their counterparts. This was done for two reasons. First, it was meant to quicken the pace at which participants were selected since they lived in groups. Secondly, it was also to prevent the inclusion of non-migrant female head porters because some authors reveal that there are traces of aboriginals who undertake the head porterage business

The instruments used for data collection were questionnaire and observation check-list. The questionnaire was structured in a manner that the research questions could be answered. The questionnaire was designed to include both closed and open-ended questions. Quantitative data included issues on their socioeconomic backgrounds like age, income earnings, expenditure as well as their responses (either YES or NO) to certain questions like whether they patronise 
orthodox or unorthodox health systems.

Observations were also made on certain conditions like their state of living, their working conditions and others. This was meant to enable the researcher to be able to draw a causal link between the health of the migrant female head porters and the observed variables. In furtherance, the study made use of both primary and secondary data. The secondary data mainly entailed journals, reports and other online sources no minority migration and health.

Concerning the data analysis, the quantitative data were compiled and thoroughly reviewed to be able to correct errors that occurred unnoticed. The data was also rationalised at this stage to enhance its internal consistency. The quantitative data were then coded into a well prepared and reviewed SPSS software (version 21) template which was used to subsequently generate tables, charts and percentages to facilitate further discussions. Discussions were then made based on observed patterns and peculiarities that were discerned from the tables and charts.

\section{Results}

\subsection{Socio-economic Information of Respondents}

The socio-economic information seeks to characterise the respondents and contextualise the human setting of the study. This helped to unearth critical variables as they influenced health care access of the female head porters in the metropolis.

\subsection{Age Distribution of Respondents}

The survey uncovered that the dominant age group in the head porterage business were those between the ages of 1620. Those below ten years, 10-15 years, 21-25 years, 26-30 years, 31-35 years constituted $9 \%, 16 \%, 15 \%, 16 \%$ and $1.5 \%$ respectively. These have been illustrated in Table 1 .

Table 1. Age Distribution of Female Head Porters

\begin{tabular}{ccc}
\hline Age Group & Frequency & Percentage (\%) \\
\hline Below 10 Years & 34 & 9.0 \\
10-15 Years & 60 & 16.0 \\
16-20 Years & 161 & 42.5 \\
21-25 Years & 57 & 15.0 \\
26-30 Years & 60 & 16.0 \\
31-35 Years & 6 & 1.5 \\
Total & 378 & 100 \\
\hline
\end{tabular}

Source: Field Survey, 2018

\subsection{Level of Educational Attainment}

The survey reveals that the level of educational attainment by the migrant female head porters is generally low. From Table 2, about thirty-seven per cent of the respondents have never had any formal education, $27.5 \%$ have had only primary education while $27.5 \%$ and $7.5 \%$ have reached JHS and SHS respectively.

Table 2. Levels of Educational Attainment

\begin{tabular}{ccc}
\hline Level of Education & Frequency & Percentage (\%) \\
\hline Primary & 104 & 27.5 \\
JHS/Middle School & 104 & 27.5 \\
SHS & 28 & 7.5 \\
Never Attended School & 142 & 37.5 \\
Total & 378 & 100 \\
\hline
\end{tabular}

Source: Field Survey, 2018 


\subsection{Length of Stay of Respondents}

Data on how long the migrant female head porters have stayed in the metropolis suggest that the head porterage activity is a complementary and a seasonal source of livelihood. The survey revealed that $72.5 \%$ had stayed there for less than a year, $19 \%$ have been there between $1-2$ years, $3.8 \%$ have spent at most four years while the rest have stayed above four years. This is depicted in Figure 1.

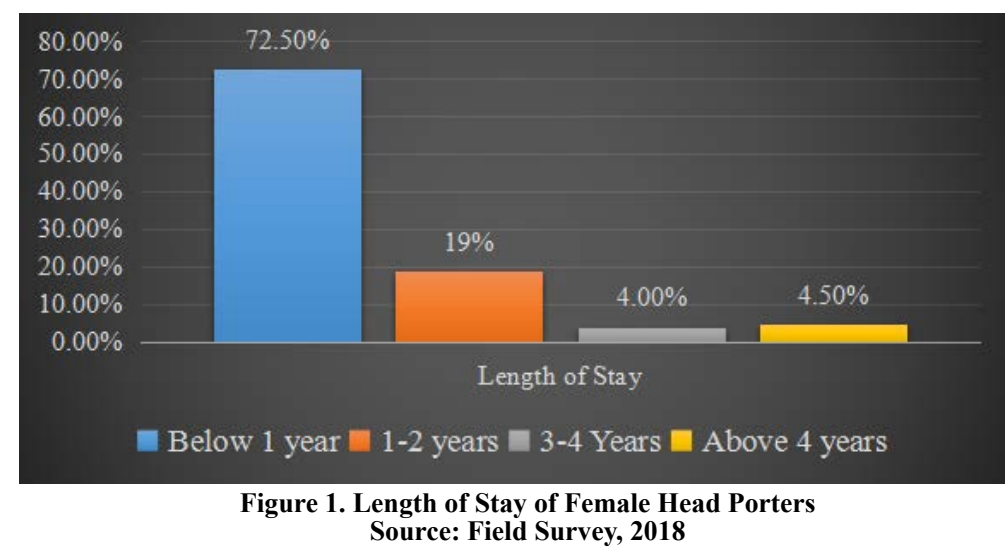

\subsection{Preferred Health Service Providers among Migrant Female Head Porters}

The preferred health service provider by most of the respondents is licensed over-the-counter shops (known locally as drug stores). The data reveal that about $67 \%$ of the respondents preferred over-the-counter medicines, $17 \%$ preferred the use of a health facility while $11 \%$ and $5 \%$ of the respondents resorted to drug peddlers and local herbalists respectively. The most important determinant for their choice of health service provider was affordability. This is illustrated in Table 3.

Table 3. Preferred Healthcare Providers among Migrant Female Head Porters

\begin{tabular}{ccc}
\hline Healthcare Provider & Frequency & Percentage (\%) \\
\hline Health Facility & 64 & 17 \\
Over-the-counter & 253 & 67 \\
Local herbalists & 19 & 5 \\
Drug Peddler & 42 & 11 \\
Total & 378 & 100
\end{tabular}

Source: Field Survey, 2018

\subsection{Reasons for Healthcare Preference among Migrant Female Head Porters}

Illustrating the relationship between the preferred health service provider and the reasons for the preference through a cross-tabulation reveals that the majority of the respondents preferred over-the-counter medicines because of how affordable it is. The study revealed that those who preferred health facilities (17\%) did so because of the quality of services they get. However, those who preferred the over-the-counter medicines (67\%), drug peddlers (11\%) and local herbalists (5\%) did so because of their affordability. The study found that $61 \%$ of the respondents preferred their choice of health service providers due to its affordability, $25 \%$ cited availability as reason for their preference while the remaining chose the quality of service. This implies that most of them do not regard the quality of treatment as the reason for accessing a particular healthcare service but rather how affordable the health service is. This implies that healthcare interventions among migrant female head porters should be largely aimed at making healthcare affordable. This is illustrated in Table 4. 
Table 4. Relationship between Healthcare Preference and Reasons for Preference Among Migrant Female Head porters

\begin{tabular}{ccccc}
\hline \multicolumn{2}{c}{ Cheaper } & & \multicolumn{2}{c}{ Why do you prefer the facility? } \\
& & Availability & Quality of service & Quality of service \\
\hline & Health facility & 8 & 6 & 50 \\
& Chemical seller & 180 & 73 & 0 \\
\multirow{2}{*}{$\begin{array}{c}\text { What type of health service provider } \\
\text { do you prefer? }\end{array}$} & Drug peddler & 22 & 20 & 0 \\
& Local herbalists & 10 & 5 & 4 \\
\hline
\end{tabular}

Source: Field Survey, 2018

\subsection{Average Daily Incomes}

Incomes of the migrant female head porters were crucial in analysing their health-seeking behaviours. The study revealed that those earning between GHS 11.00-15.00 and GHS 16.00-20.00 were the dominant groups in the metropolis each representing 28.8\% respectively. In addition, those earning between GHS 5.00-10.00 and above GHS 20.00 represent $23.8 \%$ and $16.3 \%$ respectively. Lastly, $2.5 \%$ of the respondents earned below GHS 5.00. This is elaborated in Table 5.

\begin{tabular}{cc} 
Table 5. Average Daily Income Earned by Female Head Porters \\
\hline Income Category (GHS) & Percentage \\
\hline Below 5 & $2.5 \%$ \\
$5-10$ & $23.8 \%$ \\
$11-15$ & $28.8 \%$ \\
$16-20$ & $28.8 \%$ \\
Above 20 & $16.3 \%$ \\
\hline
\end{tabular}

Source: Authors' Field Survey, April 2018

\subsection{Average Daily Expenditure}

This represents the average income spent by the migrant female head porters on daily basis. These are usually restricted to the necessities like food, water, shelter and places of convenience. The figure 2 illustrates the percentage average daily expenditures of the female head porters on the elements above. The average expenditure of the female head porters per day is GHS10.60. It is imperative to note that about $76 \%$ of their daily expenditure is spent on food. This could partly be explained by the physically demanding nature of their work which demands that their bodies be constantly nourished. 


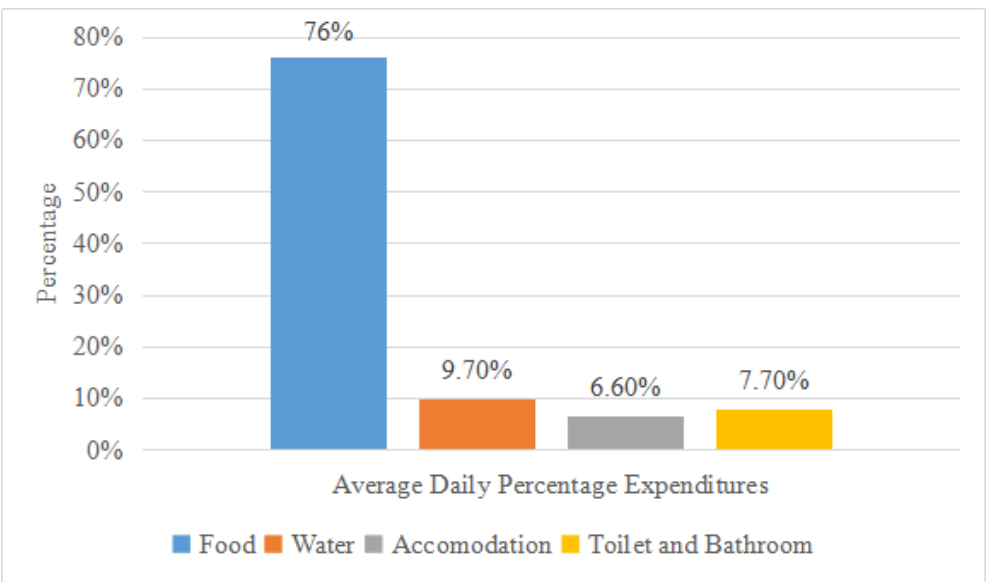

Figure 2. Percentage Daily Expenditures Source: Authors' Field Survey, April 2018

\subsection{Analysis of the Usage of Health Facilities by Female Head Porters}

The preferred health facility patronised among the migrant female head porters is clinic. The reason for this is as most respondents suggest was the closeness of the facility to their neighbourhoods. With this, $72 \%$ of the respondents remarked that the facilities were within their vicinity. The data suggest that about $75 \%$ of those who have been to a health facility use clinics, $18.7 \%$ have utilised a hospital while the rest use a pharmacy. Hence, unless there is an acute case that demanded transfer to a hospital, most of them prefer to use the clinic to save transportation cost. Figure 3 illustrates it.

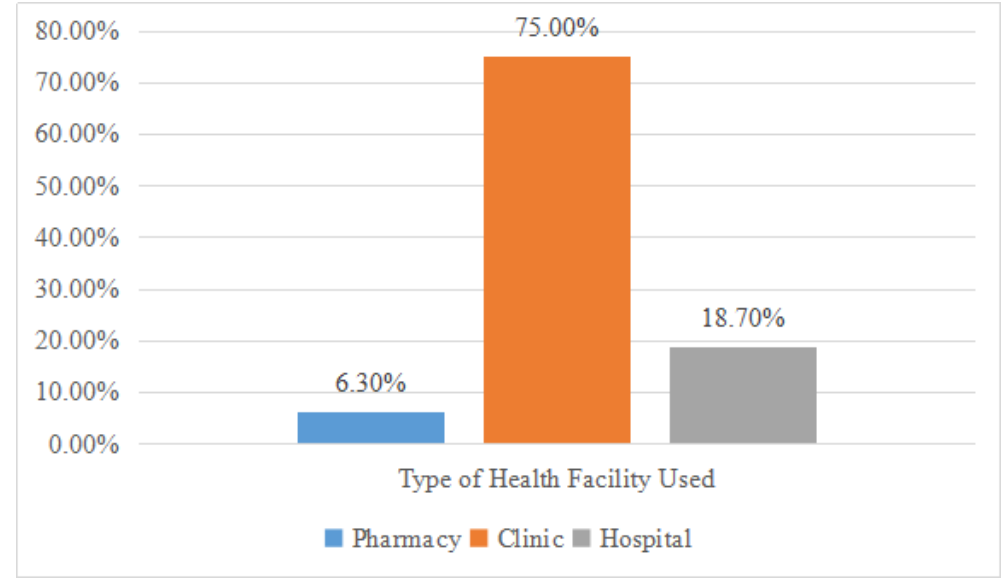

Figure 3. Type of Health Facility Used Source: Field Survey, April 2018

\subsection{Assessment of Affordability of Quality Healthcare Services}

Affordability is another relative dimension of healthcare access. It measures how the healthcare service provider's charges commensurate with the ability and willingness of the client to pay for the service. The dimension is relative because different people with different financial standings may see the same price as either being expensive or costly. Hence measuring this dimension relative to a particular price tag will be flawed. Thus, indicators like respondents' perception, whether or not they are enrolled on NHIS and others are used instead.

\subsection{Respondents' Perception on Healthcare Charges at Facilities}

From Table 6, out of the total number of respondents who had been to a health facility since becoming a migrant female head porter, $34 \%$ claimed charges at the various facilities were affordable, $50 \%$ regarded the charges as being expensive while the remaining saw them as being very expensive. This implies that about $66 \%$ of the respondents saw charges at the facilities they visited as being beyond their means. 
Table 6. Respondents' Perception on Healthcare Charges

\begin{tabular}{ccc}
\hline Perception & Frequency & Percentage (\%) \\
\hline Affordable & 129 & 34 \\
Expensive & 189 & 50 \\
Very Expensive & 60 & 16 \\
Total & 378 & 100 \\
\hline
\end{tabular}

Source: Field Survey, 2018

\subsection{Enrolment and Use of National Health Insurance Scheme (NHIS)}

The survey reveals that about $65.6 \%$ of all respondents have ever enrolled unto the scheme whereas the remaining $34.4 \%$ have not. However, only $65.6 \%$ of respondents who had been to a health facility testified that they have registered for the scheme. This in a way affects the respondents' perception of healthcare charges as majority of those not enrolled on the scheme saw the charges as high. This is explained in Table 7.

Table 7. Enrolment on NHIS by Health Facility Users

\begin{tabular}{ccc}
\hline Enrolment & Frequency & Percentage (\%) \\
\hline Yes & 248 & 65.6 \\
No & 130 & 34.4 \\
Total & 378 & 100 \\
\hline
\end{tabular}

Source: Field Survey, 2018

\subsection{Renewal of the National Health Insurance Scheme (NHIS)}

In terms of renewal, $50 \%$ of those who had enrolled on the National Health Scheme renewed the card when they expired whereas the remaining $50 \%$ were reluctant in renewing their insurance. The reasons given by most of the respondents for not renewing their health insurance card were that they were not getting the expected services any time they attend the health facility.

\subsection{Support from Peers and Association}

The study found that the migrant female head porters live in clusters and hence association with their peers goes a long to help them. However, while $38.8 \%$ of the respondents affirmed that they do help their peers when they are in need, $36.2 \%$ responded in the negative while the remaining $24.8 \%$ remarked they had no idea. The reason for the low support among the migrant female head porters could be attributed to the relatively short duration of stay by most of them.

Table 8. Support from Peers When Sick

\begin{tabular}{ccc}
\hline Support when ill & Frequency & Percentage (\%) \\
\hline Yes & 147 & 38.9 \\
No & 137 & $36.3 \%$ \\
No idea & 94 & $24.8 \%$ \\
Total & 378 & $100 \%$ \\
\hline
\end{tabular}

Source: Field Survey, 2018

Their relatively short stay has also affected their ability to join associations. According to some respondents, most of the associations get disbanded whenever the leaders go back to the north hence it will be difficult to maintain an association. That notwithstanding, $17.5 \%$ testified that they belong to associations. They represent the few who had stayed there for more than a year and hence could mobilise to form a social group to accelerate their welfare. The data 
further reveals that $74.6 \%$ of those who belong to associations testified that they had received financial support from the associations. This represents a strength in the quest to improve healthcare affordability by migrant female head porters. This is represented in the Table 9.

Table 9. Financial Support from Associations

\begin{tabular}{ccc}
\hline $\begin{array}{c}\text { Do you Receive Financial } \\
\text { Support }\end{array}$ & Frequency & Percentage (\%) \\
\hline Yes & 282 & 74.6 \\
No & 96 & 25.4 \\
Total & 378 & 100 \\
\hline
\end{tabular}

Source: Field Survey, 2018

\subsection{Assessment of Acceptability and Accommodation of Healthcare Services}

Acceptability is the extent to which the client is comfortable with the manner the health service provider operates. Accommodation, on the other hand, reflects how the operations of the health service provider is configured to meet the constraints and preference of their clients. These are all relative dimensions which depends on certain socio-cultural factors.

\subsection{Respondents' Perception on Waiting Time at Health Facilities}

The survey reveals that $9 \%$ of the respondents spent less than one hour in waiting, $36.4 \%$ spent between $1-2$ hours, $39.4 \%$ between $2-3$ hours while $15.2 \%$ spent above 3 hours. This according to most of the respondents was very frustrating as the majority of the respondents complained of excessive waiting times. This is illustrated in Table 10.

Table 10. Waiting Times at Health Facilities

\begin{tabular}{ccc}
\hline Waiting Time (hours) & Frequency & Percentage (\%) \\
\hline Below 1 & 34 & 9 \\
$1-2$ & 138 & 36.4 \\
$2-3$ & 149 & 39.4 \\
$3+$ & 57 & 15.2 \\
Total & 378 & 100 \\
\hline
\end{tabular}

Source: Field Survey, 2018

\subsection{Respondents' Perception on Attitude of Health Personnel}

From Table 11, the survey indicates that about $53 \%$ of the respondents who had accessed health facilities saw health service workers at the facilities in question as being less hospitable. However, $25 \%$ and $22 \%$ of the respondents found the health workers attitude to be very hospitable and hospitable respectively.

Table 11. Respondents' Views on Attitude of Healthcare Workers

\begin{tabular}{ccc}
\hline Respondents View & Frequency & Percentage (\%) \\
\hline Very hospitable & 95 & 25 \\
Hospitable & 83 & 22 \\
Less hospitable & 200 & 53 \\
Total & 378 & 100 \\
\hline
\end{tabular}

Source: Field Survey, 2018 


\subsection{Quality of Treatment}

Quality of treatment as inferred from the responses of most of the respondents was described based how long one's health condition remained stable after receiving treatment from the service provider. Thus, most of them described a particular health service as quality if the ailment for which they had received treatment had not resurfaced for a long time. With this, $53 \%$ of the respondents considered the quality of treatment as very poor whereas $25.6 \%$ and $21.4 \%$ considered it very good and good respectively. This is shown in Table 12.

\begin{tabular}{ccc} 
Table 12. Respondents' Views on the Quality of Treatment at Health Facilities \\
\hline Respondents View & Frequency & Percentage (\%) \\
\hline Very Good & 97 & 25.6 \\
Good & 81 & 21.4 \\
Very poor & 200 & 53 \\
Total & 378 & 100 \\
\hline
\end{tabular}

Source: Field Survey, 2018

\section{Discussion}

This study is a follow-up to an earlier publication which looked at migrant female head porters' enrolment in, renewal and utilisation of the National Health Insurance Scheme in the Kumasi Metropolis. The study examined the health-seeking behaviours of migrant female head porters in the Kumasi Metropolis. This section discusses major findings from the study to which recommended possible actions are outlined for improved accessibility to quality healthcare among migrant female head porters within the Kumasi Metropolis. The study showed that about $67.5 \%$ of the migrant female head porters are 20 years or below. This implies that majority of those in the head porterage business are in their prime years of schooling. It is also worth noting that as a seasonal business, many of these migrant female head porters get their school fees from this head porterage venture.

The age group may also be as a result of the rigorous nature of the business which requires strength in its engagement. This finding conforms with that of [13] whose study revealed that about $69 \%$ of the female respondents are aged 19 years or below. Similar findings are captured in [22]. It, however, differs from findings by [30], whose study in the Greater Accra revealed that $49 \%$ of the female head porters were aged 20 years and below. This could partly be explained by the difference in geographical contexts of the study. The age group is likely to impact on the health access of the migrant female head porters, especially those below ten (10) years who are not mature enough to decide on their health needs. Again, Educational level among migrant female head porters was also found to be low. More than fifty (50) per cent of them had not attained any formal education. The findings are in line with [5] who opined that $60 \%$ of female head porters in the CBD of the Kumasi metropolis are without formal education. In the same vein, [30] uncovered that $56 \%$ of the female head porters in the Accra metropolis do not have any formal education.

The study further revealed that about $83 \%$ of the migrant female head porters sought health care from elsewhere other than health facilities. These included over-the-counter shops (67\%), drug peddlers (11\%) and local herbalists $(5 \%)$. Respondents cited affordability as the most important determinant for their choice of health service provider. Out of the total number of respondents who had been to a health facility since coming to Kumasi as a migrant head porter, $61 \%$ of the respondents preferred their choice of health service providers due to its affordability, $25 \%$ cited availability as reason for their preference whereas the remaining chose the quality of service. This implies that most of them do not regard the quality of treatment as the reason for accessing a particular healthcare service but rather affordability of the health service. This finding corroborates $[5,16,27]$ that affordability plays a crucial role in health accessibility. It is worth noting that the use of traditional medicine is predominantly among new migrants who brought them along from their origins in the north. However, more prolonged exposure to life in the city appears to enlighten the migrants female head porters and enable them to appreciate modern ways of dealing with their ailments. The change in preference for a particular health care system by the migrant female head porters who have lived longer in the city could also be attributed to higher income. This notwithstanding, the survey revealed that only $40 \%$ of respondents have been to a health facility for health care ever since they migrated to Kumasi. This comes as no surprise since about $66 \%$ of the respondents who had accessed a health facility saw charges at the facilities they visited as being expensive. Thus, migrant female head porters in the Kumasi Metropolis 
only visit modern health facilities when their condition is grave. These findings buttress the views of ${ }^{[4]}$ that the health seeking-behaviours of the migrant female head porters include over-the-counter prescriptions, unprofessional traditional medicines and treatments among others.

Another crucial factor that affects the health-seeking behaviour of the migrant female head porters is proximity of the health facilities to their residence. The study revealed that about $75 \%$ of those who have been to a health facility used clinics and the reason by most respondents for this was the closeness of the facility to their neighbourhoods. Thus, unless there was an emergency situation that demanded transferal to a hospital, most of them preferred to use the clinic to save transportation cost. This is not different from the findings of $[16,17,18,25,26]$ that distance can be an impediment to accessing quality healthcare as the patient may not have the means to get to the health service provider. It can, therefore, be concluded that a myriad of factors influence the health-seeking behaviour of female head porters in the Kumasi Metropolis which go way beyond factors such as the age, level of education, length of stay, income level, level of savings and insurance coverage. The study also found that most of the respondents who used health facilities were dissatisfied with the quality of treatment they receive from the health service providers in question. It is imperative to note that respondents cited attitude of the health professional towards them and linguistic barriers as the main reasons for their dissatisfaction. Most of them who were not conversant in the English or Twi language were left stranded whenever they were being interrogated or diagnosed. This conforms to [1] which maintains that the attitudes of health service personnel are critical in influencing patients' satisfaction and consequently their ability to access healthcare services. He further emphasises that professionalism and good conduct by health personnel helps to repose confidence in clients and ultimately foment their desire to access healthcare.

\section{Conclusion and Policy Recommendation}

The study found that quality healthcare promotion programmes targeted at vulnerable groups such as the migrant female head porters in Ghana have long been centred on the idea that providing infrastructure and knowledge about the causes of ill health will go a long way to increase access to quality healthcare. This study has provided both empirical depth and theoretical clarification which indicate that despite the availability of health facilities and knowledge on the right healthcare system, there are several complex and multidimensional problems that the vulnerable in society such as the migrant female head porters face in accessing healthcare. These include affordability, availability, accessibility, accommodation and its acceptability. Therefore, based on the findings of the study, the following recommendations are made to improve the migrant female head porters' access to quality healthcare in the Kumasi Metropolis.

First, the government, through the Ministry of Health, the Ghana Health Service and the Ministry of Gender and Social Protection, should come out with a comprehensive national health planning policy that will target vulnerable groups in society such as the migrant female head porters to ease their financial burden in accessing healthcare. Also, the NHIS should be improved to increase enrolment on the system since evidence from the study indicates that about $81.25 \%$ of those who obtained the health facilities with their NHIS cards saw it as being helpful. The study also revealed that there is a negative perception on the efficiency of the system as $50 \%$ of respondents cited lack of confidence in the system as a reason for not enrolling it. There is, therefore, the urgent need to rebrand the system to revive hope and confidence in it. Also, there should be measures to ease the cost of enrolment and renewing the cards for migrant female head porters as many of them cited financial difficulty as the reason for their inability to enroll and remain active on the system. The National Health Insurance Authority should embark on massive public education on how the system operates to clear any misconceptions of the NHIS among migrant female head porters and the general public to increase enrolment.

Furthermore, the National Standards Authority should liaise with the Ministry of Health and the Ghana Health Service to ensure that over-the-counter operators and other drug peddlers do not prescribe or sell drugs without prescriptions from recognised health facility. This is because their prescriptions could be very dangerous to the health of the migrant female head porters as they remain unprofessionally sanction. Finally, to protect the interest of the female head porters, they should form a well-structured and coordinated association. The association will give them a united front to pursue their collective interest and protect them from all sorts of challenges they face including the difficulties they face in accessing healthcare. The study, therefore, proposes an approach that is integrated, dynamic and interactive to increase migrant female head porters' access to quality healthcare in the Kumasi Metropolis.

\section{Compliance with ethical standards}

The study was approved by the Committee on Human Research, Publication and Ethics of the School of Medical 
Sciences/Komfo Anokye Teaching Hospital with reference no. CHRPE/ AP/361/14. All participants gave verbal consent for their participation in the study.

\section{Availability of data and material}

The datasets used and/or analysed during the current study are available from the corresponding author on reasonable request.

\section{Competing interests}

The author declares that he has no competing interests.

\section{Funding}

This work was not supported by any organisation. Its contents are solely the responsibility of the author.

\section{References}

[1] Aduo-Adjei, K. Patients Satisfaction With Quality Healthcare In Ghana: A Comparative Study Between University of Ghana and University of Cape Coast Hospitals. 2015.

[2] Agyei, YA., Kumi, E., Yeboah., T. It is Better to be a Kayayei than to be Unemployed: Reflecting on the Role of Head Portering in Ghana's Informal Economy. GeoJournal. 2015. DOI 10.1007/s10708-015-9620-z.

[3] Alvi, M. A. Manual for Selecting Sampling Techniques in Research. MPRA Paper No. 70218. 2016. Available Online at: https://mpra.ub.uni-muenchen.de/70218/.

[4] Akuoko, D. R., Ansah, O. P., Ohene, B. E. Examining Female Head Porters' Access to Quality Healthcare Services in the Kumasi Metropolis; Undergraduate Dissertation submitted to the School of Education, Valley View University, in Partial Fulfilment of the Award of Bachelor of Education in Social Studies. 2018.

[5] Amoah, E. Enrollment in NHIS and Access to Healthcare: A Case Study of Migrant Female Head porters at the Central Business District of Kumasi, Ashanti Region, Ghana. A Thesis Submitted to the Department of Community Health in Partial Fulfilment Of the Award of Degree of Masters in Public Health in Health Services Planning and Management. KNUST, Kumasi. 2014.

[6] Anarfi, J., Kwankye, S., Ofuso-Mensah et al. Migration from and to Ghana: A Background Paper. Migration Development Research Centre (DRC) Working Paper C-University of Sussex, Brighton: Development Research Centre on Migration, Globalisation and Poverty. 2003.

[7] Antonovsky, A. The Salutogenic Model as a Theory to Guide Health Promotion. Health Promotion International. 1996; 11(1).

[8] Asaana, P. Migrant Health Care Practices: The Perspectives of Women Head Porters in Kumasi, Ghana. A Thesis Submitted to the School of Graduate Studies of the University of Lethbridge In Partial Fulfilment of The Requirements for The Degree Master of Arts. 2010.

[9] Assan, J. K. Experiences of Young Migrants Working in Urban Food Markets in Southern Ghana: Implications for Well-being and Social Policy. Journal of Social Science for Policy Implications. 2014; 2(3): 01-25.

[10] Awumbila, M., Ardayfio-Schandorf, E. Gendered poverty, migration and livelihood strategies of female porters in Accra, Ghana. Norsk Geografisk Tidsskrift. J Geol. 2008. https://doi.org/10.1080/00291950802335772.

[11] Awumbila, M. Internal Migration, Vulnerability and Female Porters in Accra, Ghana. 2007. Available at:http://www. paa2007.princeton. edu/download.aspx?submissionId $=70865$.

[12] Awuni, A. S. The Missing Link in Human Resource Development: The Case of Female Head porters (Kayayei) in Ghana. Thesis Submitted to the School of Business, College of Art and Social Sciences, Kwame Nkrumah University of Science and Technology, Kumasi, In Partial Fulfilment of The Requirements for The Award of Degree of Doctor of Philosophy (PhD) In Management Studies. 2015.

[13] Baah-Ennumh, T.Y. Amponsah O. and Adoma MO. The Living Conditions of Female Head Porters in the Kumasi Metropolis, Ghana. Journal of Social and Development Sciences. 2012; 3(7):229-244.

[14] Bakewell, O. and Haas, H. D. African Migrations: Continuities, Discontinuities And Recent Transformations. 2007. 10.1163/ej.9789004161139.i-185.38.

[15] Bhattacherjee, A. Social Science Research: Principles, Methods, and Practices. Second Edition. Published under the Creative Commons Attribution-Non-commercial-ShareAlike 3.0 Unported License. University of South Florida, USA. 2012.

[16] Boateng S., Amoako P., Poku A.A. et al. Migrant female head porters' enrolment in and utilisation and renewal of the 
National Health Insurance Scheme in Kumasi, Ghana. J Public Health. 2017; 25:625-634. DOI 10.1007/s10389-0170832-1.

[17] Buor, D. Analysing the socio-spatial inequities in the access of health services in sub-Saharan Africa: Interrogating geographical imbalances in the uptake of health care. A professorial inaugural lecture, KNUST. 2008.

[18] Du K., Zhang K. and Tang S. Challenges for child health in the Western Pacific. A draft report on MCHPAF study in China, World Bank. 2001.

[19] Foresight Report. Migration and Global Environmental Change. Future challenges and opportunities. 2011.

[20] Ghana Statistic Service (GSS). 2010 population and housing census Report. GSS, Accra. 2012.

[21] Jehu-Appiah, C., Aryeetey, G., Spaan, E., et al. Equity aspects of the National Health Insurance Scheme in Ghana: Who is enrolling, who is not and why? Social Science and Medicine. 2011; 72(2):157-165. https://doi.org/10.1016/ j.socscimed.2010.10.

[22] Kwankye S.O., Anarfi, J. K., Tagoe, C. A. et al. Coping Strategies of Independent Child Migrants from Northern Ghana to Southern Cities. Working Paper Issued by the Development Research Centre on Migration, Globalisation and Poverty. Arts C-226, University of Sussex, Brighton. 2007.

[23] Mandersheid, R. Challenges to Accessing Care [online]. 2013. Available at: http://www.nhis.gov.gh [Retrieved March $16,2014]$.

[24] Opare, J. A. Kayayei: The Women Head Porters of Southern Ghana. Journal of Social Development in Africa. 2003; $18(2)$.

[25] Parez, A., Farber, S., Mercado, R. G.et al. Accessibility to healthcare facilities in Montreal Island: An application of relative accessibility indicators from the perspective of senior and non-senior residents. International Journal of Health Geographics Part1: Children, National Center for Health Statistics. 2010. Vital Health Stat 10(196).

[26] Schoeps, A., Gabrysch, S., Niamba, L. et al. The effect of distance to health-care facilities on childhood mortality in rural Burkina Faso. American Journal of Epidemiology. 2011; 173(5):492-498.

[27] Shamsu-Deen, Z. Migration and Health among Female Porters (Kayayei) in Accra, Ghana. Thesis Submitted to the University of Ghana, Legon in Partial Fulfilment of the Requirement for the Award of a Doctor of Philosophy Degree in Migration Studies. 2015.

[28] Wilson, A. Resources for Thriving among Female porters in Accra. A Qualitative study of Migrants from Northern Ghana to Greater Accra Region. A Salutogenic Approach. Thesis submitted to the Department of Health Promotion and Development Faculty of Psychology, University of Bergen, Norway. 2012.

[29] Wrigley-Asante, C. Influence of male or female headship on the keeping and care of small ruminants: the case of the transitional zone of Ghana. 2008.

[30] Yeboah, M. A. and Appiah-Yeboah, K. An Examination of the Cultural and Socio-Economic Profiles of Porters in Accra, Ghana. Nordic Journal of African Studies. 2009; 18(1): 1-21.

[31] Yin, R. K. Case Study Research: Design and Methods. Applied Social Research Methods Series. Volume 5. Sage Publications, London, 2009. 